\title{
How Manufacturing Affects the Development of World City: A Case Study of Guangzhou in China
}

\author{
Wei Li ${ }^{1 *}$, Desheng Xue ${ }^{2}$ and Xu Huang ${ }^{3}$ \\ 1 Research Center for Urban and Regional Studies, Department of Geography and Planning, Sun Yat-sen \\ University,Guangzhou 510275;liw26@mail2.sysu.edu.cn \\ 2 Research Center for Urban and Regional Studies, Department of Geography and Planning, Sun Yat-sen \\ University,Guangzhou 510275; eesxds@mail.sysu.edu.cn \\ 3 Research Center for Urban and Regional Studies, Department of Geography and Planning, Sun Yat-sen \\ University,Guangzhou 510275; huangx253@mail.sysu.edu.cn \\ * Correspondence: liw26@mail2.sysu.edu.cn; Tel.: +86-159-0205-9519
}

\begin{abstract}
In the world city theory, most researchers focus on the service sector in the urban economy and less discuss the role of manufacturing. However, the path of only emphasizing financial and corporate service could not fit the sustainability concept. Compared to Anglo-American world city, Global South's world cities have distinct pathway to be industrialization, tertiarization and globalization. This paper adopted dynamic historic perspective with first-hand materials including in-depth interviews with managers and government officers and second-hand data including yearbook statics and economic census to closely examine the emerging world city-- 'World Factory' in Global South, Guangzhou in China, from 1949 to 2015, to emphasize how manufacturing affect the urban globalization through three dimensions, economic, social and spatial dimensions. To make the confirmation of the role of manufacturing in Guangzhou as sustainable world city, we find manufacturing in Guangzhou builds up the basic foundation of export-oriented economy and makes positive effects on urban economic transformation. In addition, manufacturing remains important source of employment and foreign immigration. Along with urbanization and industrialization, urban spatial expansion and aggregation changes with different urban development concept. We provide new insights on multiple globalization on manufacturing for sustainable world city.
\end{abstract}

Keywords: manufacturing; world city; sustainable development; Guangzhou China

\section{Introduction}

"World City", deeply impacted by the globalization and urbanization, has attracted unprecedented research upsurge in the field of urban research, and scholars tried to build a set of theory to analyze the path for being world city with specialized characteristics. Concerning the definition of world city and sustainability involving various fields, like economic, social, culture etc., our research only focuses on the economic field. Currently, Large body of literature analyzes world city as financial and corporate service center and its service network[1-3], whereas production function has been largely forgotten. However, the path of only emphasizing financial and corporate service could not fit the sustainability concept[4] and after the economic crisis, it witnesses the typical world city model, London and New York that have experienced great declined. Is manufacturing significant for world city's sustainability? If the answer is yes, then how or why manufacturing affect the development of world city? To answer these two questions, our study tried to analyze the development course of Guangzhou's manufacturing and its effects on economic, social and spatial dimensions to find out whether manufacturing is significant for world city's sustainable development or not.

There is no doubt that manufacturing is important for urban industrialization and some researchers claimed that industrialization is another phase before globalization. It's evident that this 
insufficiency stems partly from the dominance of theoretical or globalist perspective on the developed world with post-industrial Anglo-American cities' development experiences, neglecting the Global South's different development pathways [5-7]. For some world cities in Global South, its globalization is in the process of industrialization and urbanization. Guangzhou, emerging world city in Global South, could be typical example to emphasize the production's role in world city's development. In addition, from the new urban planning from New York and London, the concept of re-industrialization has been mentioned. Hence, if we want to make a sustainable development of world city, we not only develop industry with global impacts, but also develop multiple industries including manufacturing and construct coordinated industrial structures.

Although some scholars have realized the urgent need to redirect urban economic development towards real sector manufacturing instead of only focusing on the financial sector's as "dealer economy" to keep sustained growth, especially after the recent global economic crisis, they lack to provide detailed case study for long-term periods to show the changing function of manufacturing for world city's formation guided by the sustainable development idea, as most of their researches were adopted global scale to describe city network at specific time[8-10]. This article could provide city-level analysis for the changes affected by manufacturing on the economic, social and spatial dimensions of Guangzhou to have a better answer to explain the process of urban sustainable globalization. In addition, to enrich the multiple globalization in the world city theory, we follow Olds and Yeung[11], Krätke[9], to highlight the need for attention directed towards multi-pathways on world city, especially on manufacturing dynamics in Global South's world cities.

With this background, the structure of the paper is as follows. Firstly, we review the literatures and tried to answer whether manufacturing could promote cities to be global city or not from historical experience and explain why we should not ignore the influence of real sectors in world city's formation. Secondly, we use Guangzhou's socioeconomic data and spatial maps as evidence to examine the influence of manufacturing on economic, social, and spatial three dimensions in contemporary emerging world city's globalization process. Finally, we discussed on manufacturing engine's impact on Global South's world city and look forward to the future of world city's prospects and possible diverse pathway for sustainability.

\section{Manufacturing in World Cities}

To trace back to the principle concept of world city, it was first academic mentioned by Patrick Geddes[12] to describe those cities which have great ports and have global influence of international trade in the world[13]. Then Friedmann[14] pointed out the world city hypothesis on world city's function and characteristics with seven index to measure the world city ranking that are major financial center, headquarters of transnational companies(including regional headquarters),rapid growth of business services sectors, important manufacturing center, etc. With the new international division of labor[15], the global control functions of world cities are directly reflected in the structure and dynamics of production sectors and employment. At that time, manufacturing was the main production sector. In 1990s, based on New York, London and Tokyo's model, "Global City" concept[16] came out. Corporate headquarters and international financial institutions and agencies are more emphasized[17], but Sassen still mentioned that world city should be as sites of production, including the production of innovations in leading industries[18]. From the above classic world city theory, we could found that manufacturing has its own irreplaceable status in world city's formation.

Nevertheless, for the empirical study, few contributions have been made to describe the manufacturing's role in world city. One of the precedent finding is from Rodriguez and Feagin. Rodriguez and Feagin[19] chose three pairs of cities, Amsterdam--Leiden (during the period of Dutch Hegemony), London--Manchester (during the period of British hegemony) and New York--Houston (during the period of US hegemony), to show the dynamics of world city formation with financial center and industrial center respectively as particular types of economic activities, which named as urban specialization. Rodriguez explained Leiden (during the period of Dutch 
Hegemony), Manchester (during the period of British hegemony) and Houston (during the period of US hegemony)have developed leading industry, respectively textile industry, automobile manufacturing industry and petrochemical industry, to have substantial world-level impact in enlarging materials and commodity markets, attracting migrant labor, and extending international commerce. They claimed production specialization, could also like financial service, serve as an essential foundation for the development and consolidation of world cities, but the research was carried out without detailed statistical analysis in each case.

Subsequently, Hill and Kim[6] argue that Tokyo and Seoul represent different type of world city because of their industrial policies and state institutions. Unlike New York model, Tokyo and Seoul have not experienced severe manufacturing decline. On the contrast, they still keep high-tech manufacturing increase and those productions are still concentrated in cities.[20, 21] Taipei [22] and Singapore [23] also show similar industrial structures. Though tertiary industry has been in a dominant position, they still grasp leading positions on some high-tech manufacturing. These researches provided evidence that manufacturing still played a significant role in current world city. But the main arguments of these articles were focused on the developmental state that the difference of the industrial structure was the result of the different state institutions' policy, not on the industrial itself effect. And some would name these cities as "second cities" [24], globally active in nonfinancial industries to separate from world city.

Actually, taking into account the structural diversity of the worldwide economy system, there should diversified sectors in world city. Some researchers pointed out multiple globalizations[9] to emphasize the diversity, particularly manufacturing's importance in world city's theory. Currently, some researches on Chinese cities have proved the multiple pathways to world city formation[5]. China, as the biggest country in Asia has been continuously ranked first for manufacturing-output in the world after 2010, strongly connected to international division of labor and global industry transfer. And more Chinese cities have been ranked into world city list and their ranking got increasing higher [25-27]. Existing literature studying on Chinese world city centers in Hong Kong, Beijing and Shanghai. Firstly, they found manufacturing did accelerate the foreign-oriented economy in the industrialization periods with more foreign direct investment focusing on manufacturing. On the other hand, these cities are evolving from manufacturing centers to advanced service centers [28-31]. Service sector become more important than manufacturing. Inspired by above researches, we conclude that manufacturing could promote urban economic internationally. But does it mean we should abandon manufacturing to develop service sectors after industrialization? Obviously, the answer is no. In fact, although industrial transformation would happen with urban globalization, the manufacturing itself also experience industrial upgrading. And this is easily neglected when existing researchers analyzed the urban industrial transition. Secondly, they found manufacturing made great impact on urban social and spatial adjustment[11, 32]. These earlier researches only investigate the social and spatial transformation from the industrialization background. When we looked back, these impact also linked with urban globalization as in Chinese city, the industrialization, globalization and even tertiarization[33] happen at the same time. We need to update our perspective to analyze the changes on social and spatial pattern affected by manufacturing. Accompanied by the industrialization, globalization and tertiarization, this context is quite different from Anglo-American world cities, and therefore manufacturing's role in world city's development path would be various as well. Only the path fit the background of world city itself, the world city could be long-term harmonious develop. And for most of the Global South's world city, manufacturing is inseparable background for sustainable development in world city

\section{Materials and Methods}

We adopt dynamic historic perspective with comprehensive long-term industrial data to analyze how manufacturing affect the urban globalization in Guangzhou. From this point, we can make the contribution to provide a solid empirical state that some world cities in Global South have links with transnationally extended production networks and continue to play an important role in 
the manufacturing upgrading[34].

Why choose Guangzhou? Guangzhou, core world city in the 'world factory'--Pearl River Delta, could be the best example to remedy the shortcomings of the above research and illustrate the changing role of manufacturing in urban globalization in Global South. Firstly, Guangzhou is the third world city in mainland China, after Shanghai and Beijing and the only one Chinese city of which world city ranking keep increasing, not decline once. Secondly, Guangzhou has its diversified economic structure to be a sustainable world city. On the one hand, it has a long history of commercial culture as international trade port city in the world. On the other hand, it has the most well-developed industry system in southern China with 35 industrial sectors (national total is 41). Thirdly, Guangzhou is the preferred city to develop exported-oriented economy and internationalized itself by industrialization[35]. In 1979, Guangzhou as the capital of Guangdong province was one-step ahead to attracted large amounts of foreign investment from Hong Kong, Taiwan, and Macau. Nearly 80\% of foreign investment was concentrated in Guangzhou at that time. In 1984, the central government further opened 14 coastal ports cities including Guangzhou to have more preferential policies and rights to approve foreign projects. Guangzhou Economic and Technological Development Zone was established at that time, one of the first state-level development districts, aimed to develop modern industry, to utilize foreign capital and to improve the structure of export products. Until now, Guangzhou city, including suburban area, like Panyu, Conghua, Huadu, Zengchen with a total population of $8.5 \times 107$ with permanent registered households and $8.8 \times 10^{4}$ foreigners registered, was the central city of the Pearl River Delta Economic Area, which was the major base of the foreign-oriented economy in China, later developed to the World Factory in the world.

Moreover, we synthesize the theory on sustainable development and the classic theory on world city and use first-hand and second-hand data to analyze the significance of manufacturing in urban economic, social and spatial dimension to prove the importance of manufacturing in sustainable world city (Figure 1). For economic analysis, we adopt economic census and statistical yearbooks to prove the fundamental status of manufacturing in urban globalization. We adopt several indexes, GDP growth and its proportion, FDI amount and its resource, to illustrate the indispensable effects in urban globalization.

For social analysis, we adopt statistical yearbooks, population statistics and interviews with foreigner managers to examine the impact of manufacturing in urban society. For spatial dimension, we adopt land-use survey data and interviews with local land use management government and companies to explore the results and outcomes from changes concept of industrial land uses.

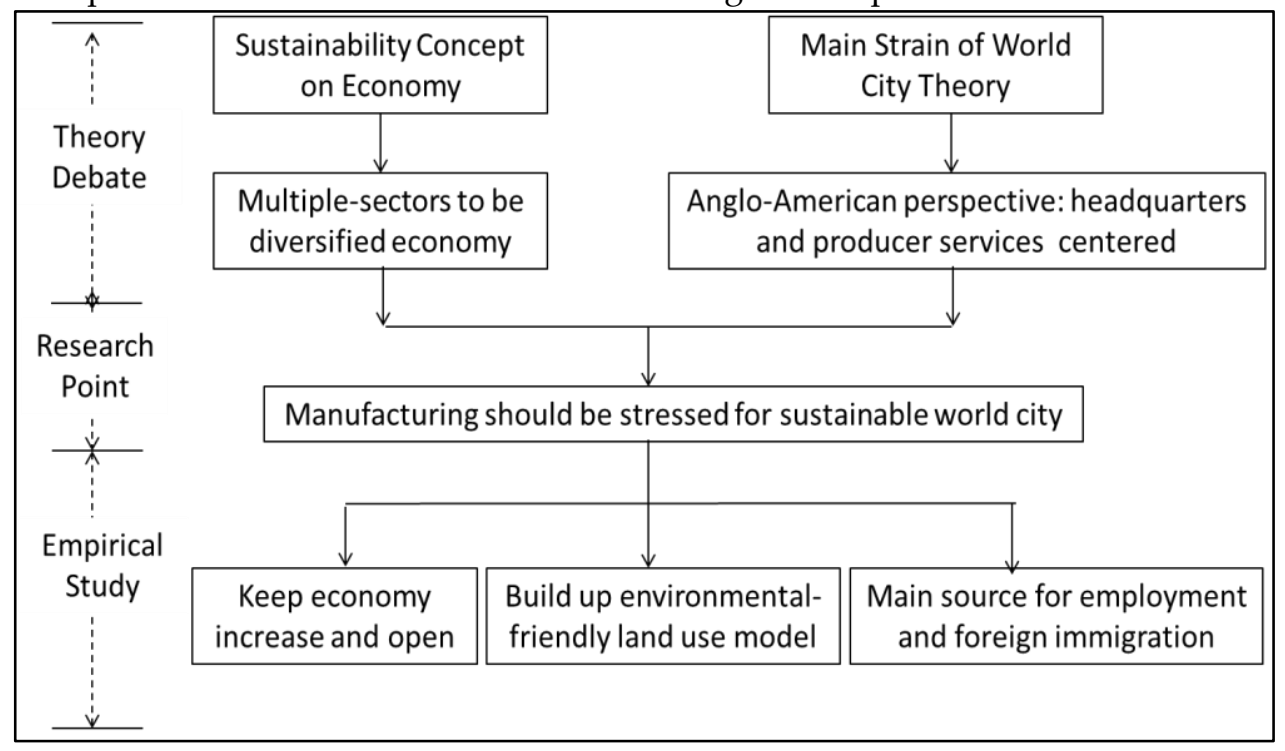

Figure 1. Framework of the research

\section{Results}




\subsection{Manufacturing keeps increase for Guangzhou's economy}

Compared to Anglo-American world cities, Guangzhou's manufacturing still played important role in city's industrialization and transformation for its increasing amount of the nominal Gross Domestic Product (GDP) of manufacturing, and steadily advanced economic structure of manufacturing-led and higher value of advanced manufacturing.

Firstly, manufacturing remains the driving force for city' economy, though industrialization and tertiarization occurred side by side in Guangzhou[33]. Table 1 presents that both manufacturing and service industry increased after year 1949. From 1949 till 2015, manufacturing has grown rapidly in Guangzhou. GDP of manufacturing increased from 96.13 million yuan in 1949 to 518.56 billion yuan in 2015 with annual increase rate $3.85 \%$. Even during the recent global financial crisis, the nominal GDP of manufacturing still keep rise. In 2016, the growth rate of industrial added value in Guangzhou (6.5\%) is higher than the national level (6\%); and also, higher than Beijing (5.1\%) and Shanghai (1.1\%). In comparison with service, it's not until mid-1990 that the nominal GDP of manufacturing was surpassed by the service sector. However, the GDP of manufacturing did not decline when service industry increased. On the contrary, the GDP of manufacturing increased over ten times after the later decade. This pattern does not fit the conventional knowledge of world city, in which a pattern is believed that the GDP of manufacturing would decline instead of the increase service[36].

Table 1. Gross Domestic Product in Main Years

\begin{tabular}{|c|c|c|c|c|c|c|c|}
\hline \multirow{4}{*}{ Year } & & & & & & \multirow{4}{*}{$\begin{array}{l}\text { Per Capita } \\
\text { GDP } \\
\text { (yuan) }\end{array}$} & \multirow{4}{*}{\begin{tabular}{|l} 
Per Capita \\
GDP \\
(USD)
\end{tabular}} \\
\hline & \multicolumn{5}{|l|}{ Gross } & & \\
\hline & \multirow{2}{*}{$\begin{array}{l}\text { Domestic } \\
\text { Product }\end{array}$} & \multirow{2}{*}{$\begin{array}{l}\text { Primary } \\
\text { Industry }\end{array}$} & \multirow{2}{*}{$\begin{array}{l}\text { Secondary } \\
\text { Industry }\end{array}$} & \multirow{2}{*}{$\begin{array}{l}\text { Tertiary } \\
\text { Industry }\end{array}$} & \multirow{2}{*}{\begin{tabular}{|l|} 
In GDP \\
\#Industry
\end{tabular}} & & \\
\hline & & & & & & & \\
\hline 1949 & 29845 & 8170 & 9854 & 11821 & 9613 & 121 & \\
\hline 1955 & 85172 & 14512 & 32968 & 37692 & 30121 & 274 & \\
\hline 1960 & 164097 & 14906 & 102435 & 46756 & 95437 & 452 & \\
\hline 1965 & 180348 & 25033 & 101444 & 53871 & 93401 & 457 & \\
\hline 1970 & 266600 & 31234 & 170872 & 64494 & 164979 & 641 & \\
\hline 1978 & 430947 & 50287 & 252479 & 128181 & 243585 & 907 & \\
\hline 1980 & 575497 & 62438 & 313734 & 199325 & 295337 & 1160 & \\
\hline 1985 & 1243623 & 120449 & 658130 & 465044 & 577048 & 2302 & 784 \\
\hline 1990 & 3195952 & 257288 & 1362975 & 1575689 & 1180978 & 5418 & 1133 \\
\hline 1995 & 12591974 & 734606 & 5780268 & 6077100 & 4934092 & 16207 & 1941 \\
\hline 2000 & 24927434 & 943718 & 10216241 & 13767475 & 8779835 & 25626 & 3096 \\
\hline 2005 & 51542283 & 1302159 & 20452183 & 29787941 & 18439550 & 53809 & 6569 \\
\hline 2010 & 107482828 & 1885645 & 40022658 & 65574525 & 36449611 & 87458 & 12882 \\
\hline 2015 & 181004136 & 2268409 & 57260783 & 121474944 & 51856341 & 136188 & 21835 \\
\hline
\end{tabular}

Source: Guangzhou Annual Statistical Yearbook (various issues).

Secondly, concerning the growth rate and quality, secondary industry, especially manufacturing performed better than service industry. Figure 2 shows the relative contribution of manufacturing and services to nominal GDP increase after 1990.Between 1990 to 2000, secondary industry, especially manufacturing rise rapidly with the highest growth rate is $16.3 \%$ in 1993 and contributed more than other two industries. After 2000, due to the industrial transformation, secondary industry increases slowly with the contribution rate decrease to about $5 \%$. Nevertheless, some researchers analyze three-year moving average growth rate of main service sectors and found that except wholesale, retail and catering industry, other service industries show the decrease trend of growth rate. They suspect service sectors contribute more growth rate to GDP is because of the greater decreasing amplitude of manufacturing growth rate, not for the service increase itself[37]. 


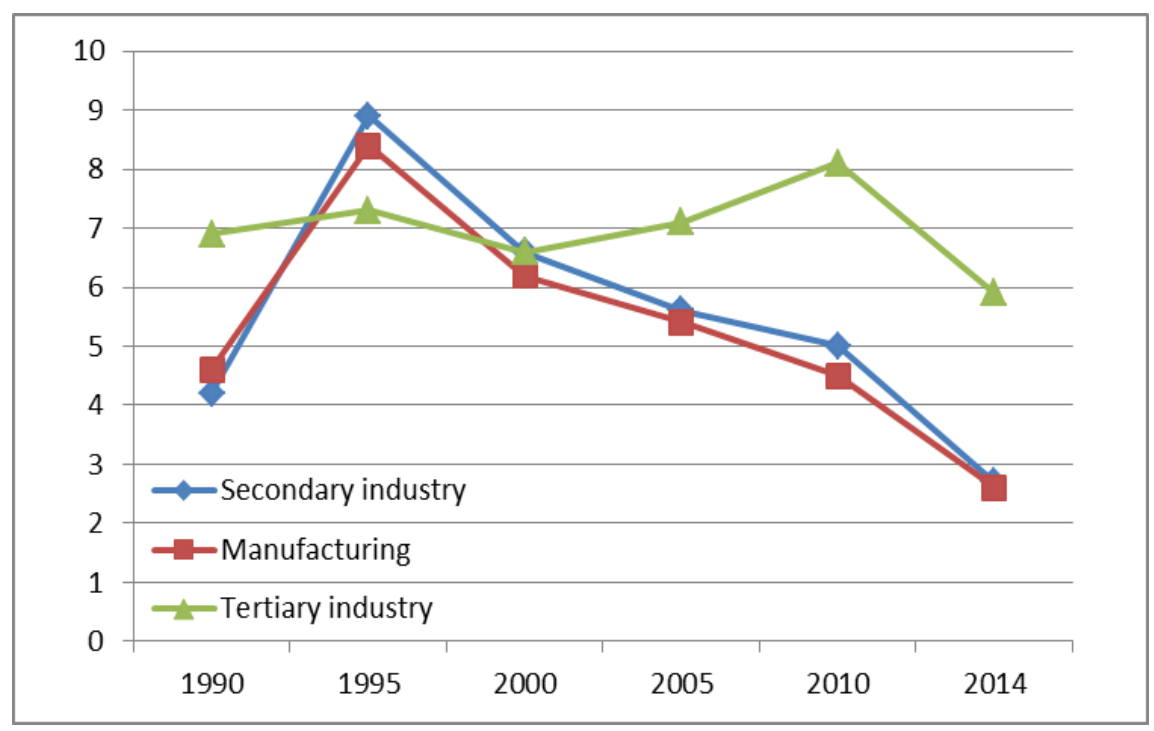

Figure 2. Contribution of Industry to the Growth of GDP (1990-2015)

Thirdly, the structure of industry itself has experienced the industry upgrading. Figure 3 demonstrate the structure change of industry in main year. During the first three five-year plans, the gross output value of light industry was higher than that of heavy industry. Until year 2004, the gross output value of heavy industry surpassed the light industry. Dai[38] shows that Guangzhou is experiencing the initial stage of industrial transformation and the leading industries, transportation equipment manufacturing, chemical raw materials and chemical products manufacturing, are still without replacement. The three pillar industries are still automotive manufacturing, petrochemical industry and electronic appliance manufacturing since 2000. From year 2010 to 2015, three pillar industries proportion of all industrial enterprises on number of units, was range from $19.46 \%$ to $23.83 \%$; on employed persons was from $26.07 \%$ to $30.95 \%$; gross output value was from $48.01 \%$ to $48.25 \%$, total profits was from $56.05 \%$ to $64.29 \%$. The state also tried to keep stimulating manufacturing upgrading and get more value added in the global value chain. For example, in the "three years action implementation plan of Industrial Transformation and upgrading in Guangzhou (2015-2017 years)", local state would spend 3 billion yuan as financial support for industrial transformation and upgrading. Among the 3 billion yuan, 800 million yuan was specifically to support industrial production and efficiency expansion, intelligent transformation (including machine substitution), equipment renewal, and innovation capability improvement etc.

Without the accumulation of manufacturing development, Guangzhou's economy could not keep steady increase in recent 30 years and could not have the foundation to be sustainable world city. 


\section{2. Manufacturing maintain close relations with international economy}

One of the significant characteristic of manufacturing in Guangzhou is export-oriented. Being open and inclusive helps urban sustainable develop, as it always can keep the commodity, capital and information flow.

Before the door-open policy, Guangzhou has made good use of its geographical advantages and exported some goods to Hong Kong, Soviet and nearby south-east countries. Guangzhou's products (Guang huo) have gained good reputation for its lower price and good quality mainly occupied the Southeast Asian and nearby regions. In 1956, 1000 Guangzhou battery "Jianhang" brand exported to Hong Kong, which became the first export battery business. Later from 1958 to 1966 , its export output occupied about $80 \%$ of the national export of similar products. In 1958, near $90 \%$ of canned were produced in Guangzhou canned factory and sold to the Soviet Union and Eastern European countries

After 1978, Guangzhou is one of the forefronts of reform and opening up and attracts most of foreign investment. By 2014, contracted foreign capital was up to 8.276 billion dollars. Of this total, 8.04 billion dollars, nearly $97.2 \%$ was foreign direct investment. And the amount of foreign capital actually used was 5.44 billion; about 93.9\% was FDI (Table. 2). More importantly, most of the foreign capital inflowed to the manufacturing sectors (Figure.4). In 2015, based on statistics on foreign funded enterprises registered by departments of industry and commerce, nearly $40 \%$ of total investment was concentrated in manufacturing, nearly twice more than real estate, second ranking item and the number of enterprises was up to $4595,20 \%$ of the total foreign funded enterprises, only after wholesale and retail trade enterprises. Until 2016, there are 288 Top 500 multinational companies invested approximate 800 projects in Guangzhou, among 120 companies established headquarters or regional headquarters. More and more advance technology companies preferred Guangzhou to transfer high-technique sectors. For example, Cisco China innovation center planned to build the world's first-class park, which is worth more than 100 billion yuan per year. GE (General Electric) cooperated with BeiGene, globally focused biopharmaceutical company to build factory in the international biology park. And Foxconn invested high-signal panel production line up to 61 billion yuan in suburban area in Guangzhou.

Table 2. Statistics on Utilization of Foreign Capital in Main Years

\begin{tabular}{|c|c|c|c|c|c|c|}
\hline \multirow[t]{2}{*}{ Year } & & & \multicolumn{2}{|l|}{ Amount of } \\
\hline & $\begin{array}{l}\text { of- } \\
\text { Contracts } \\
\text { (unit) }\end{array}$ & $\begin{array}{l}\text { \#Foreign } \\
\text { Direct- } \\
\text { Investme } \\
\text { nt }\end{array}$ & $\begin{array}{l}\text { Foreign- Capital } \\
\text { (USD 10000) }\end{array}$ & $\begin{array}{l}\text { \#Foreign } \\
\text { Direct- } \\
\text { Investme } \\
\text { nt }\end{array}$ & $\begin{array}{l}\text { Foreign Capital } \\
\text { Actually- } \\
\text { Used } \\
\text { (USD 10000) }\end{array}$ & $\begin{array}{l}\text { \#Foreign } \\
\text { Direct- } \\
\text { Investme } \\
\text { nt }\end{array}$ \\
\hline
\end{tabular}




\begin{tabular}{l|l|l|l|l|l|l}
\hline 1978 & 2 & & 53 & & & \\
1980 & 1379 & 21 & 24905 & 24794 & 3013 & 1287 \\
1985 & 4394 & 290 & 70175 & 51575 & 15782 & 10389 \\
1990 & 2711 & 389 & 55426 & 47183 & 27263 & 18613 \\
1995 & 2564 & 1774 & 685657 & 673101 & 225298 & 214444 \\
2000 & 1445 & 647 & 163454 & 152759 & 311541 & 298923 \\
2005 & 1599 & 1061 & 366155 & 340205 & 284128 & 264882 \\
2010 & 1170 & 980 & 505928 & 497384 & 408121 & 397862 \\
2014 & 1324 & 1155 & 827560 & 803975 & 543905 & 510707 \\
2015 & -- & 1429 & -- & 836335 & - & 541634 \\
\hline
\end{tabular}

Source: Guangzhou Annual Statistical Yearbook (various years).

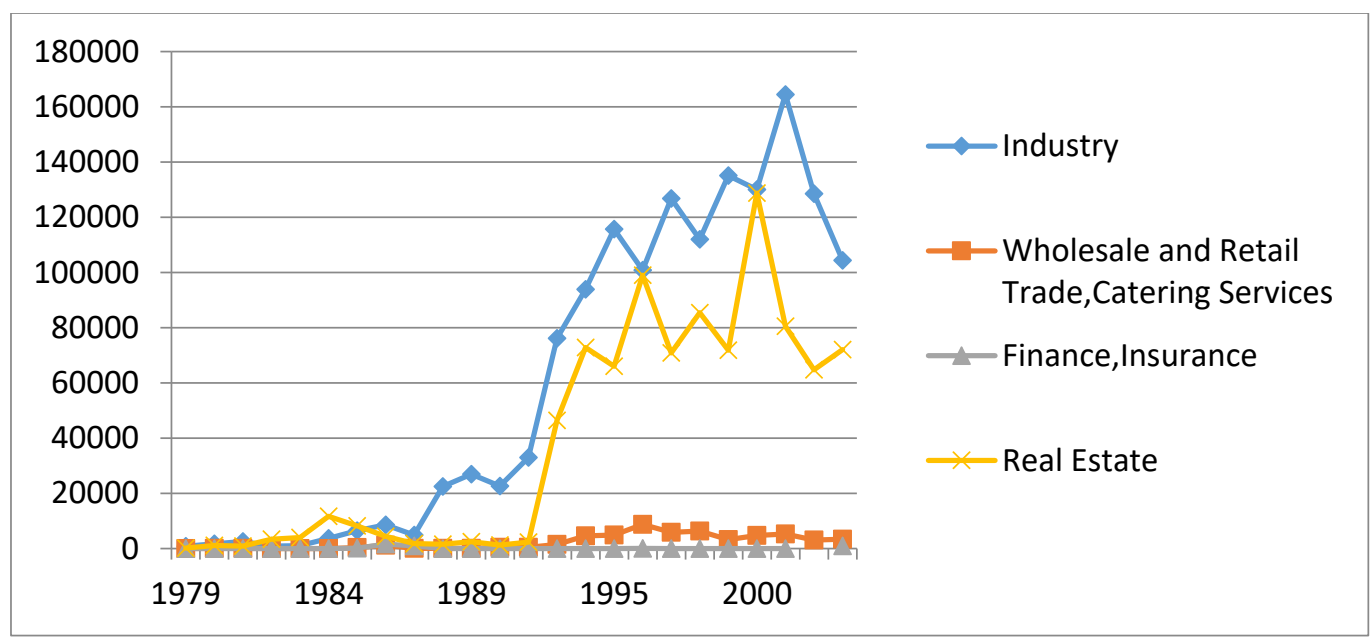

Figure 4. amount of Foreign Direct Investment Capital Actually Used by Category (1979-2015) Source: Guangzhou Annual Statistical Yearbook (various years).

Not only foreign enterprises entered into Guangzhou, but also local manufacturing corporations invest into foreign markets. In 2000, central government supported Chinese enterprises to set up branches in other countries to "going global". Enterprise from Guangzhou began to lead the world's manufacturing in some newly-industry. For instance, Chinese drone maker Ehang Inc. in Guangzhou unveiled what it calls the world's first drone capable of carrying a human passenger at the Consumer Electronics Show in Las Vegas in 2016 and shocked the world with this high-tech product. Nearly $70 \%$ of the unmanned aerial vehicle produced in Guangzhou was exported to the global market. In 2016, led by the "one belt one road" strategy, Guangzhou enterprises have set up 31 companies (branches) along the routes with 8.1billion dollars. Guangzhou companies took active part in Malaysia Malacca Marine industrial park, the Saudi Zazan economic city and other overseas industrial parks.

From Guangzhou's export-oriented manufacturing experience, we could conclude that except advanced producer serviced mentioned by Sassen, manufacturing maintain close relations with international economy to keep Guangzhou economic open and inclusive and these relations are becoming more and more close with more and more value-added. Open and inclusive economy is essential for urban sustainability. Manufacturing could improve it as well.

\subsection{Manufacturing remains important source of employment and foreign immigration}

In 1978, 32.13\% of employers, 857 thousand people were engaged in secondary industry. After one decade, the number surpassed the agriculture employed, become the main industry to absorb employments, occupying nearly 37\% of total employment. Though after 2000 the major composition of employment changed to service sector, the employment of secondary industry steadily increased to over 1 million, not like London-New York model to decline (Table.3). Table 4 shows more clearly on employment structure, that manufacturing remains the most employed 
sector with 2,620,603 persons and $32.32 \%$ of total, higher than the wholesale and retail trade, 1,586,399 persons with 19.56\%,rangking second sector for total employments. From 2013 to 2015 , manufacturing increased $10.9 \%$ while wholesale and retail trade decreased $2 \%$.Therefore, if we investigate the employments structure by categories, manufacturing remains one of the largest sectors for urban employments for the nearly two decades, which could not to be neglected for social stability.

Table 3. Employed Persons and Composition by Three strata of Industry in Main Years

\begin{tabular}{|c|c|c|c|c|c|c|c|}
\hline \multirow[t]{2}{*}{ Year } & \multirow{2}{*}{$\begin{array}{l}\text { Employed } \\
\text { Persons(pers } \\
\text { on) }\end{array}$} & & & & \multicolumn{2}{|c|}{$\begin{array}{l}\text { Composition } \\
\text { Persons=100) }\end{array}$} & (Employed \\
\hline & & $\begin{array}{l}\text { Primary } \\
\text { Industry }\end{array}$ & $\begin{array}{l}\text { Secondary } \\
\text { Industry }\end{array}$ & $\begin{array}{l}\text { Tertiary } \\
\text { Industry }\end{array}$ & $\begin{array}{l}\text { Primary } \\
\text { Industry }\end{array}$ & $\begin{array}{l}\text { Secondary } \\
\text { Industry }\end{array}$ & $\begin{array}{l}\text { Tertiary } \\
\text { Industry }\end{array}$ \\
\hline 1978 & 2668989 & 1165987 & 857527 & 645475 & 43.69 & 32.13 & 24.18 \\
\hline 1980 & 2750467 & 1106432 & 922756 & 721279 & 40.23 & 33.55 & 26.22 \\
\hline 1985 & 3134739 & 979869 & 1180526 & 974344 & 31.26 & 37.66 & 31.08 \\
\hline 1990 & 3411513 & 963548 & 1241813 & 1206152 & 28.24 & 36.4 & 35.36 \\
\hline 1995 & 4077775 & 924969 & 1583686 & 1569120 & 22.68 & 38.84 & 38.48 \\
\hline 2000 & 4962579 & 956596 & 1982905 & 2023078 & 19.27 & 39.96 & 40.77 \\
\hline 2010 & 7110695 & 590223 & 2736424 & 3784048 & 8.3 & 38.48 & 53.22 \\
\hline 2015 & 8109881 & 628668 & 2869003 & 4612210 & 7.75 & 35.38 & 56.87 \\
\hline
\end{tabular}

Source: Guangzhou Annual Statistical Yearbook (various years).

Table 4. Employed person and composition by three strata of industry (Year-end of 2015)

\begin{tabular}{lrr}
\hline \multicolumn{1}{c}{ Item } & $\begin{array}{c}\text { Employed } \\
\text { persons }\end{array}$ & $\begin{array}{r}\text { Composition } \\
\text { (\%) }\end{array}$ \\
\hline Agriculture, Forestry, Animal Husbandry and Fishery & 629254 & 7.76 \\
Industry & 2620603 & 32.32 \\
Construction & 254530 & 3.14 \\
Wholesale and Retail Trade & 1586399 & 19.56 \\
Transport, Storage and Post & 452275 & 5.58 \\
Hotels and Catering Services & 478421 & 5.9 \\
Information Transmission, Software and Information Technology & 195578 & 2.41 \\
Services & 116913 & 1.44 \\
Financial Intermediation & 253883 & 3.13 \\
Real Estate & 278731 & 3.44 \\
Leasing and Business Services & 174941 & 2.16 \\
Scientific Research, Technical Services & 61020 & 0.75 \\
Management of Water Conservancy,Environment and- Public & 350160 & 4.32 \\
Facilities & 287570 & 3.54 \\
Service to Households, Repair and Other Services & 131092 & 1.62 \\
Education & 66271 & 0.82 \\
Health and Social Work & 172240 & 2.12 \\
Culture, Sports and Entertainment & & \\
Public Management, Social Security and Social Organizations & & \\
\hline Source: Gung & & \\
\hline
\end{tabular}

Source: Guangzhou Annual Statistical Yearbook (2015).

In the meantime, Guangzhou provided not only an abundant source of domestic labor, which enabled to achieve economies of scale in consumer manufacturing, but also attracted skilled workers or professional foreign immigration on advance manufacturing. From the research of corporate project, we had interviewed with personnel departments in foreign companies over 2000-2007, the amount of Japanese companies in Guangzhou was from 105 to 320 with the increasing Japanese immigration to 5400 registered in consulate in 2007.Among 
them, nearly $75 \%$ of Japanese immigration in Guangzhou works on automobile industry including related auto-spare parts and equipment manufacturing and sales industry[39]. These kinds of international immigration also bring multiple cultures to enrich Guangzhou's urban society which would be important for sustainability for world city[40].

\subsection{Changing Industrial Land Use Policy and its outcomes}

In the first twenty years after the reform and opening up policy in 1978, urban industrial land expanded rapidly by the external and internal factors. On the one hand, the external factor is the third international transfer of manufacturing industry, especially from Hong Kong and Taiwanese manufacturing. They need large amounts of land to build up new factories for their transferring production. On the other hand, the reform of rural economic systems allowed foreign capital to inflow to rural area to stimulate rural development. Hence, township enterprises, as typical industrial actors are the main land user for low-prize or zero-prize land cost to develop labor-intensive industry. With the development of highway, railway and urban road network, some preferred to locate along the transportation line and the industrial land use pattern changed from scattered distribution to liner or belt one. However, this development model was at the cost of inefficiency of land use and environmental pollution, which is non-sustainable.

At the end of the 1990s, local government realized the problem of this unsustainable developmental path and decided to change to meet the new era's needs. To build up more friendly-environmental surroundings with high efficiency industry chain, local government built up several high-technique industrial zones. One of the famous industrial zones was the Guangzhou Economic and Technological Development District (GETDD), which was viewed as milestone for industrial transformation mode. GETDD's initial goal was to introduce foreign investment to develop high-tech industries and export-products processing industries. Municipal government invested modern public infrastructure and implemented supporting policies to attract industry into the development zone to improve the land use efficiency and agglomeration economy. Industrial development has also gradually transformed from labor intensive to technology and capital intensive. After the early twentieth century, with the concept of sustainable development, local government further emphasized the improvement of efficiency and environmental protection. Closing the severe polluting industrial enterprises, optimizing industrial sites, promoting high-tech and environment-friendly, ecological industries are the practice of the sustainable industrial path.

As one of the leading industry in Guangzhou, auto-manufacturing also experiences huge industry upgrading for more efficiency and more environmental-friendly. We have done some surveys and interviews with managers in auto-manufacturing in Guangzhou. One typical example is that the company $\mathrm{H}$ invested to build a zero-pollution factory through the latest productive technique. The managers from that company said it owns to the changes of the management concepts of smart factory with small, simple and compact idea. This production path with $100 \%$ recycling not only improves the efficiency of resource use, including land, water and so on, but also improves the environmental conditions. Local government very encouraged these kinds of production path and granted the company title with excellent model on environment protection. Currently, smart factory is the core concept for sustainable production model.

\section{Discussion and Conclusion}

This paper tried to make the confirmation of the role of manufacturing in Guangzhou as sustainable world city and analyze how manufacturing made effects on the changes of economic, social dimension and urban industrial land use from 1949 to 2015. Compared with 
classic world city theory from Friedmann and Sassen, our study illustrates different sustainable development path in industrial integration. Firstly, manufacturing in Guangzhou have kept increase with industrial upgrading. Although its proportion to total GDP has declined, its absolute value has never declined. Along with the higher status of world city ranking, its own industry structure changes from light-industry-dominant to heavy-industry-dominant with more value added and technique requirements. Secondly, manufacturing maintains close link to international market and attracts more and more foreign capital on competitive multinational advanced manufacturing in Guangzhou. Thirdly, on the social dimension, manufacturing remained the largest sector to absorb employment instead of wholesale and trade services. Moreover, industry attracted skilled and professional foreign immigration to improve international cooperation and enrich multi-culture in urban society. Fourthly, the changes on urban land use pattern also reflect the changes of urban development concept on sustainability: from extensive development with lower industry technology and efficiency to compact model with advanced technology, higher management level and productivity. The concepts of smart factories become the mainstream of the modernist way of building factory and organizing production.

From the Guangzhou case of Global South's world city, we realize that the industrialization and tertiarization happened together, which differ from Western experiences. As the latecomer, Guangzhou utilized the experience from Global North, and highly valued the manufacturing's role in city. With initial stage of urban spatial sprawl to provide sufficient land for industrial development to later increase land use efficiency to implement cluster policy to promote industrial upgrading, Guangzhou provide diversified paths to utilize foreign force and domestic development demands to be more international competitive in real sector development. The case of Guangzhou enriches the dynamic pathway for being world city and presents solid empirical research on multiple globalizations based on the long-term periods' analysis. The role of production could also reflect the key cities' global control on global capital, and unfortunately without the Global South's experience, these comments were easily neglected compared to Global North's world city discussion. The case of Guangzhou, as the typical example of Global South, tried to raise researcher's attention on manufacturing, particularly advanced manufacturing in urban globalization's process. Learning lessons from the economic crisis on virtual economy, world city need rethink of service economy and its own traditional production history to promote the healthy development of the real and virtual economy in the world[41]. Multiple globalizations with diversified industries could be the path for sustainable development of world city.

Acknowledgments: This work was supported by International Cooperation and Exchange Program of the National Natural Science Foundation of China (No. 41320104001); and the Fundamental Research Fund for the Sun Yat-sen University (No. 17lgjc04).

Author Contributions: Wei Li and Desheng Xue conceived and designed the research; $\mathrm{Xu}$ Huang contributed analysis tools of economic and social dimensions; Wei Li drafted the manuscript; and Desheng Xue revised the whole paper.

Conflicts of Interest: The authors declare no conflict of interest. The founding sponsors had no role in the design of the study; in the collection, analyses, or interpretation of data; in the writing of the manuscript, and in the decision to publish the results.

\section{References}

1. Beaverstock, J. V.; Smith, R. G.; Taylor, P. J., A roster of world cities. Cities 1999, 16, (6), 445-458.

2. Taylor, P. J., Specification of the World City Network. Geographical Analysis 2001, 33, (2), 181-194.

3. Taylor, P. J.; Derudder, B., World City Network: A global urban analysis. Routledge: 2015.

4. Cohen, M., A Systematic Review of Urban Sustainability Assessment Literature. Sustainability 2017, 
9, (11), 2048.

5. Chubarov, I.; Brooker, D., Multiple pathways to global city formation: A functional approach and review of recent evidence in China. Cities 2013, 35, (4), 181-189.

6. Hill, R. C.; Kim, J. W., Global Cities and Developmental States: New York, Tokyo and Seoul. Urban Studies 2000, 37, (12), 2167-2195.

7. Wei, Y. D.; Chi, K. L.; Luo, J., Globalizing Shanghai: foreign investment and urban restructuring. Habitat International 2006, 30, (2), 231-244.

8. Krätke, S., Global pharmaceutical and biotechnology firms' linkages in the world city network. Urban Studies 2013, 51, (6), 1196-1213.

9. Krätke, S., How manufacturing industries connect cities across the world: extending research on 'multiple globalizations'. Global Networks 2014, 14, (2), 121-147.

10. Martinus, K.; Tonts, M., Powering the world city system: energy industry networks and interurban connectivity. Environment \& Planning A 2015, 47, (7), 1502-1520.

11. Olds, K., Globalizing Shanghai: the 'Global Intelligence Corps' and the building of Pudong. Cities 1997, 14, (2), 109-123.

12. Geddes, P., Sir, Cities in evolution : an introduction to the town planning movement and to the study of civics. Social Theories of the City 1915, 4, (3), 236-237.

13. Hall, P. G., The world cities. McGraw-Hill: 1966.

14. Friedmann, J., The World City Hypothesis. Development \& Change 1986, 17, (1), 69-83.

15. Frobel, F.; Heinrichs, J.; Kreye, O.; Burgess, P.; Snidal, D., The New International Division of Labour: Structural Unemployment in Industrialized Countries and Industrialization in Developing Countries. American Journal of Sociology 1982.

16. Sassen, S., Global City. Global City 1991, 18, (3), 621-645.

17. Derudder, B., On Conceptual Confusion in Empirical Analyses of a Transnational Urban Network. Urban Studies 2006, 43, (11), 2027-2046.

18. Sassen, S., The Global City:New York, London, Tokyo. Princeton University Press: 2013; p 501-502.

19. Rodriguez, N. P.; Feagin, J. R., Urban Specialization in the World-System An Investigation of Historical Cases. Urban Affairs Review 1986, 22, (2), 187-220.

20. Fujita, K.; Hill, R. C., Global Toyotaism and Local Development. International Journal of Urban \& Regional Research 1995, 19, (1), 7-22.

21. Fujita, K.; Hill, R. C., Industrial Districts and Economic Development in Japan: The Case of Tokyo and Osaka. Economic Development Quarterly 1998, 12, (2), 181-198.

22. Wang, C. H., Taipei as a Global City: A Theoretical and Empirical Examination. Urban Studies 2003, 40, (2), 309-334.

23. Olds, K.; Yeung, H., Pathways to global city formation: a view from the developmental city-state of Singapore. Review of International Political Economy 2004, 11, (3), 489-521.

24. Hodos, J., Globalization and the Concept of the Second City. City \& Community 2007, 6, (4), 315333.

25. Derudder; Peter; Taylor; Michael; Hoyler; Pengfei; Xingjian; Miaoxi; Zhao; Shen, Measurement and Interpretation of Connectivity of Chinese Cities in World City Network, 2010. Chinese Geographical Science 2013, 23, (3), 261-273.

26. Shi, Y.; Hamnett, C., The potential and prospect for global cities in China: in the context of the world system. Geoforum 2002, 33, (1), 121-135.

27. Taylor, P.; Derudder, B.; Hoyler, M.; Ni, P.; Witlox, F., City-dyad analyses of China's integration into the world city network. Urban Studies 2014, 51, (5), págs. 868-882.

28. Taylor, B.; Kwok, R. Y.-W., From Export Center to World City: Planning for the Transformation of Hong Kong. Journal of the American Planning Association 1989, 55, (3), 309-322.

29. Wu, F., The Global and Local Dimensions of Place-making: Remaking Shanghai as a World City. Urban Studies 2000, 37, (8), 1359-1377.

30. Tao, Z.; Wong, Y. C. R., Hong Kong: From an Industrialised City to a Centre of Manufacturing-related Services. Urban Studies 2002, 39, (12), 2345-2358.

31. Yusuf, S., Pathways to a World City: Shanghai Rising in an Era of Globalisation. Urban Studies 2002, 39, (7), 1213-1240.

32. Lia, Z.; Wu, F., Socioeconomic transformations in Shanghai (1990-2000): Policy impacts in globalnational-local contexts. Cities 2006, 23, (4), 250-268.

33. Lin, G. C. S., Toward a Post-Socialist City? Economic Tertiarization and Urban Reformation in the Guangzhou Metropolis, China. Eurasian Geography \& Economics 2004, 45, (1), 18-44.

34. Henderson, J.; Dicken, P.; Hess, M.; Coe, N.; Yeung, H. W.-C., Global production networks and the 
478

479

480

481

482

483

484

485

486

487

488

489

490

491

492

493

494

495

analysis of economic development. Review of International Political Economy 2002, 9, (3), 436-464.

35. Xu, J.; Yeh, A. G. O., Guangzhou. Cities 2003, 20, (5), 361-374.

36. Clark, C., The conditions of economic progress. Macmillan: 1951.

37. Jiang, H. Y.; Yang, Q. S., 我国城市发展转型中制造业重要性分析: 以广州为例. Economic Geography 2012, 32, (8), 78-83. (EN: Analysis on the importance of manufacturing industries in the process of urban economic transition: taking Guangzhou as an example)

38. Dandan, D.; Chunshan, Z., 1995 年以来广州市产业转型特征研究. Economic Geography 2012, (11), 81-88. (EN: Study on the characteristics of the Industrial transformation for Guangzhou since 1995)

39. Yungang, L.; yue, C., 广州日本移民族裔经济的形成及其社会空间特征. Acta Geographica Sinica 2014, (10), 1533-1546. (EN:Global economy, local landscape: Study on the ethnic economy of Japanese expatriates in Guangzhou city)

40. Lin, G.; Wang, L., 全球化背景下酒吧的地方性与空间性一一以广州为例. 地理科学 2011, (07), 794-801. (EN: Placeness and spaciality of bar under globalization:case of Guangzhou city,China)

41. Desheng, X.; Hemian, H., 关于世界城市研究的两场争论及其对相关研究的影响. Progress in Geograhpy 2013, (08), 1177-1186. (EN: Two debates and two trends: Review on world city research) 